\title{
ALTITUDINAL DISTRIBUTION OF ASTERACEAE INVADERS, AUSTROEUPATORIUM INULIFOLIUM AND AGERATINA RIPARIA, IN THE DISTURBED FOREST OF BATUKAHU NATURE RESERVE, BALI
}

\author{
Laily Mukaromah ${ }^{1 *)}$ \\ ${ }^{{ }^{*}}$ Purwodadi Botanic Garden-Indonesian Institute of Sciences (LIPI), Pasuruan, Jawa Timur \\ *Email: laily.mukarromah@gmail.com
}

\begin{abstract}
Biological invasions are a major threat to biodiversity worldwide. Here, we aim to assess the occurrence of two invasive Asteraceae, Austroeupatorium inulifolium and Ageratina riparia, and the extent of their distributional range along altitudinal gradients in Mt Pohen, Batukahu Nature Reserve, Bedugul, Bali. The cover abundance of Austroeupatorium inulifolium and Ageratina riparia were measured by establishing 92 plot samples in four different forest conditions encompassed elevational ranges from the lowest (forest borders) to the highest elevation of Mt Pohen. Results showed that the abundance of both Asteraceae invaders were strongly correlated with disturbed habitats located at lower elevation. The forest borders at these forest sites were characterized by dense thicket of Austroeupatorium inulifolium and high abundance of Ageratina riparia. Both Asteraceae invaders reach their maximum altitudinal range up to the highest peak of the Mt Pohen. Results highlight that high abundance of these Asteraceae invaders which forms dense cover may lead to major forces of change in plant communities and forest ecosystem.
\end{abstract}

Kata kunci: Biological invasions; Asteraceae; Austroeupatorium inulifolium; maximum altitudinal range; Batukahu Nature Reserve

\section{INTRODUCTION}

Austroeupatorium inulifolium and Ageratina riparia are listed as aggressive invaders in Global Compendium of Weeds. Both invaders have the ability to regenerate and rapidly invade natural and agricultural ecosystems and have been identified as having strongly negative environmental impacts. Ageratina riparia is native to Central America and has emerged a serious invasive weed in many tropical and warm temperate regions of the world. Originated from Central America, nowadays Austroeupatorium inulifolium pose as a severe weed in areas of agricultural ecosystems and nature reserve (Haluwana and Madawala 2013).

Batukahu Nature Reserve plays a critical role in supporting biodiversity and forest conservation of mountain ecosystems in Bali; consisting forest habitats and large lakes system in the surrounding area. However, this reserve has been greatly modified by a long history of human disturbance, such as logging, conversion of forest into settlements, plantation and agriculture, and geothermal mining; all factors promote the spread and establishment of invasive plants. The present study addresses the patterns of Austroeupatorium inulifolium and Ageratina riparia and the extent of their distributional range along altitudinal gradients in Mt Pohen, Batukahu Nature Reserve, Bedugul, Bali.

\section{METHODS}

The study was conducted in Mt Pohen, Batukahu Nature Reserve, Bedugul, Bali (Figure 1); it is about $60 \mathrm{~km}$ North of Denpasar City. The Batukahu Nature Reserve occupied an area of $1.762,80$ ha and has been protected since 1974. It consists of Batukahu I (Tapak), Batukahu II (Pohen) and Batukahu III (Lesong). Most area on these mountain regions is higher than $1000 \mathrm{~m}$ in altitude and the highest peak is 2089 meter above sea level, with annual precipitation is $2000 \mathrm{~mm}$ per year.

\subsection{Field data collection}

The invasive Asteraceae were sampled in October 2013. The cover abundance of Austroeupatorium inulifolium and Ageratina riparia were measured by establishing 92 plot samples along four different forest tracks encompassed elevational ranges from the lowest (forest borders) to the highest elevation of $\mathrm{Mt}$ Pohen. The transects were stratified by four different forest conditions:

1) less disturbed sites (forest sites affected by low intensity fire),

2) undisturbed sites,

3) highly disturbed sites (forest sites affected by high intensity wildfires located at the lower elevation),

4) moderately disturbed sites (forest sites affected by high intensity wildfires) 
Along the walking trails, the occurrence of Austroeupatorium inulifolium and Ageratina riparia outside the quadrat were also recorded.

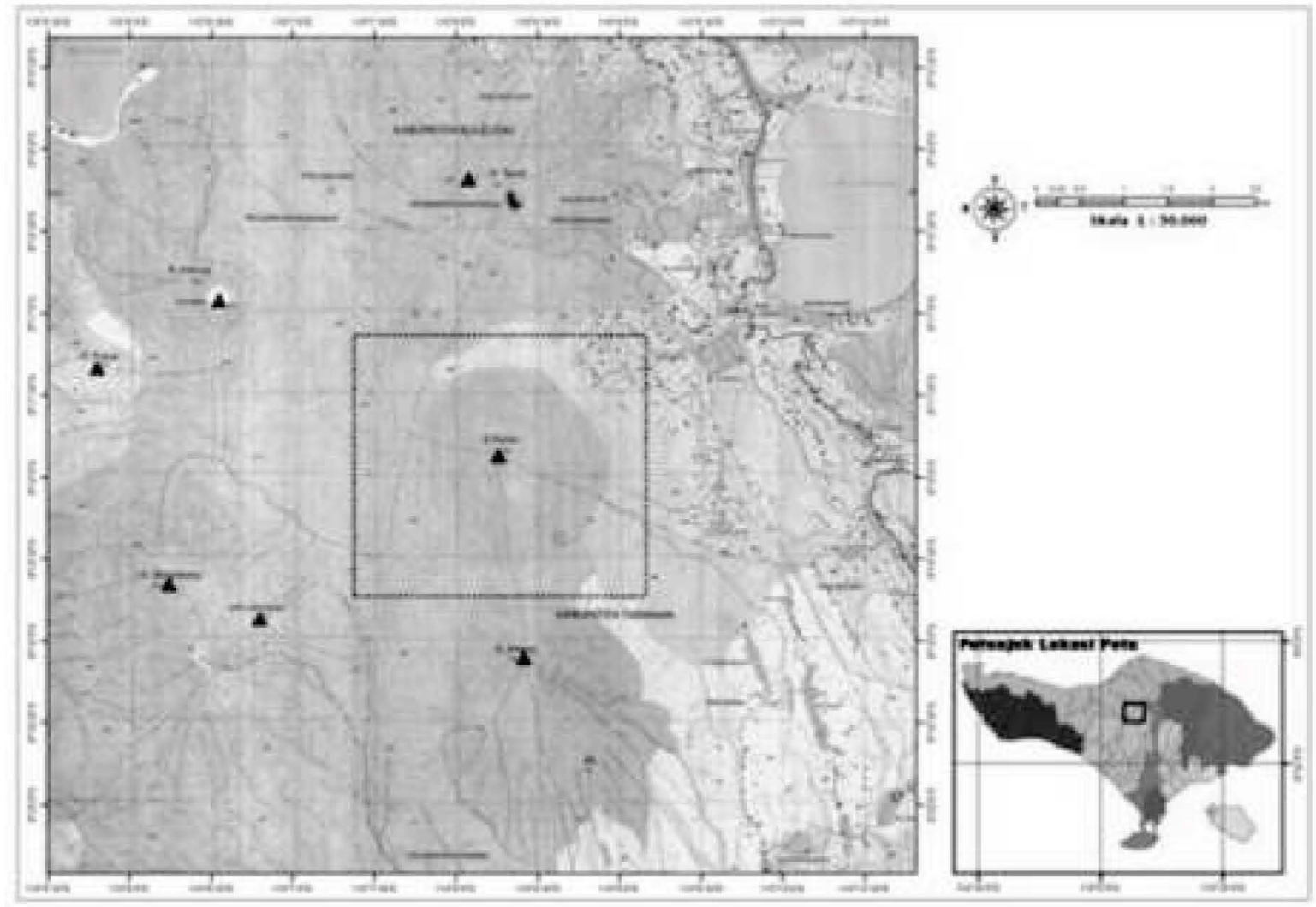

Figure 1. Map of study area in Bedugul Nature Reserve, Bali. Rectangular shows the study site of this study.

\subsection{Data analysis}

PC-ORD software was used to model the distribution and abundance of exotic Austroeupatorium inulifolium and Ageratina riparia. To examine the extend distribution of both invaders along the altitudinal gradients, cover abundance of both species were plotted on the contour map using Arc GIS software.

\section{RESULTS AND DISCUSSION}

\subsection{Invasive species abundance related to site characteristics}

The results showed that coverage of both invasions were highly variable on these forest sites (Figure 2). The abundance of $A$. inulifolium and $A$. riparia were mostly associated with disturbed habitats. A. inulifolium occurred most abundantly in site 4 and site 3 ; while $A$. riparia also showed its abundance related to site 3 , followed by site 4 (Figure 2). A. riparia also occurred quite abundant in site 1 (less disturbed sites) and site 2 (undisturbed sites); particularly found smothering the understory vegetation along the forest tracks in the undisturbed forest.
Studies have shown that disturbed forest sites are more vulnerable to species invasion than the undisturbed sites (Dawson et al. 2011; Hobbs and Huenneke 1992; Richardson and Pyšek 2006). In this study, the highly disturbed sites (site 3) were highly invaded in comparison to other sites, as they correspond to forest borders having higher constancy and occupancy of introduced species than those of the intact forest plots. This site 3 was the forests sites affected by wildfires; characterized by open canopy and located at the lower elevation correspond to forest borders. Field observations showed that these forest borders are noticeably invaded by both invaders. The suitability of these "disturbed" habitats combined with high propagule pressure might lead to rapid colonization by these alien plant species.

Disturbance often results forest openness which provides more resources (light, space, and resource) for invasive plants to rapidly establish and populate. In the disturbed sites which likely had the impact of high severity of the fire, forest vegetation has been altered significantly, and a striking feature was also reflected by dense impenetrable thicket of $A$. inulifolium particularly found in lower altitude sites (Figure 3). A. inulifolium is a perennial shrub forming dense scrambled bushes $1-5 \mathrm{~m}$ in height. It 


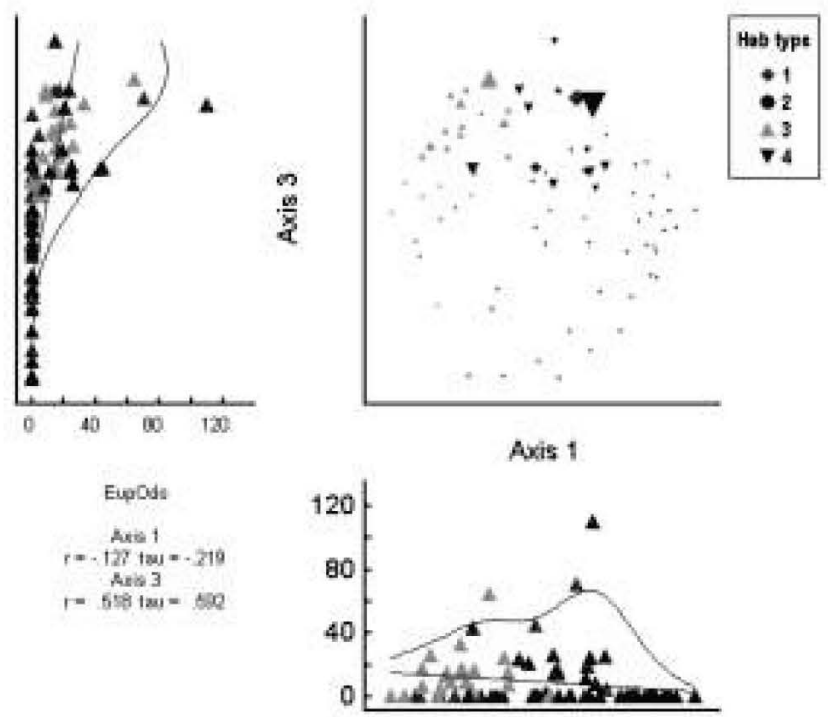

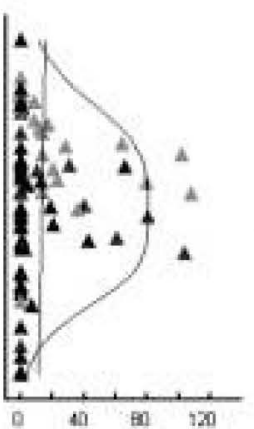
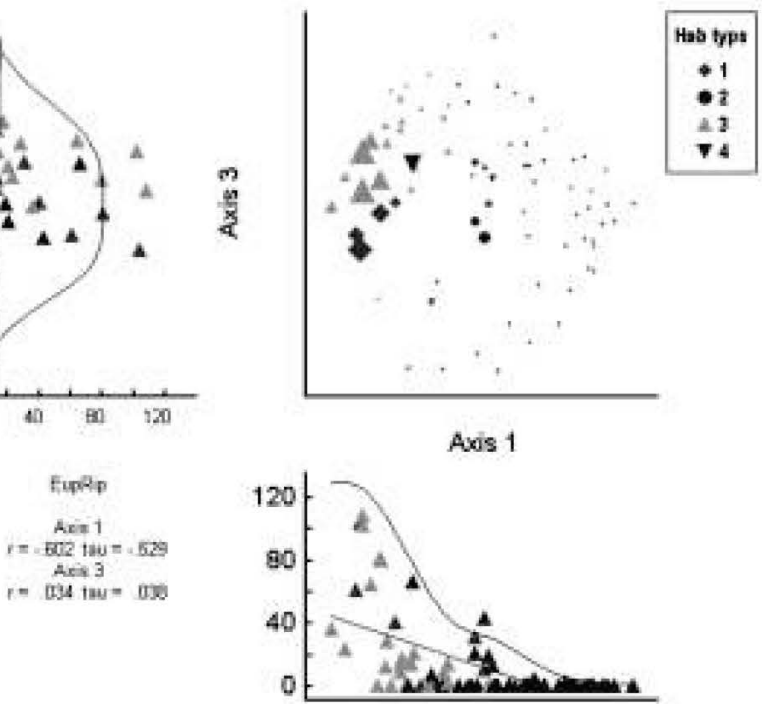

Figure 2. Patterns of $A$. inulifolium (left) and A. riparia (right) based on the proportion of species cover abundance plotted on the environmental gradients. Description of habitat types: 1) less disturbed sites, 2) undisturbed sites, 3) highly disturbed sites, 4) moderately disturbed sites.
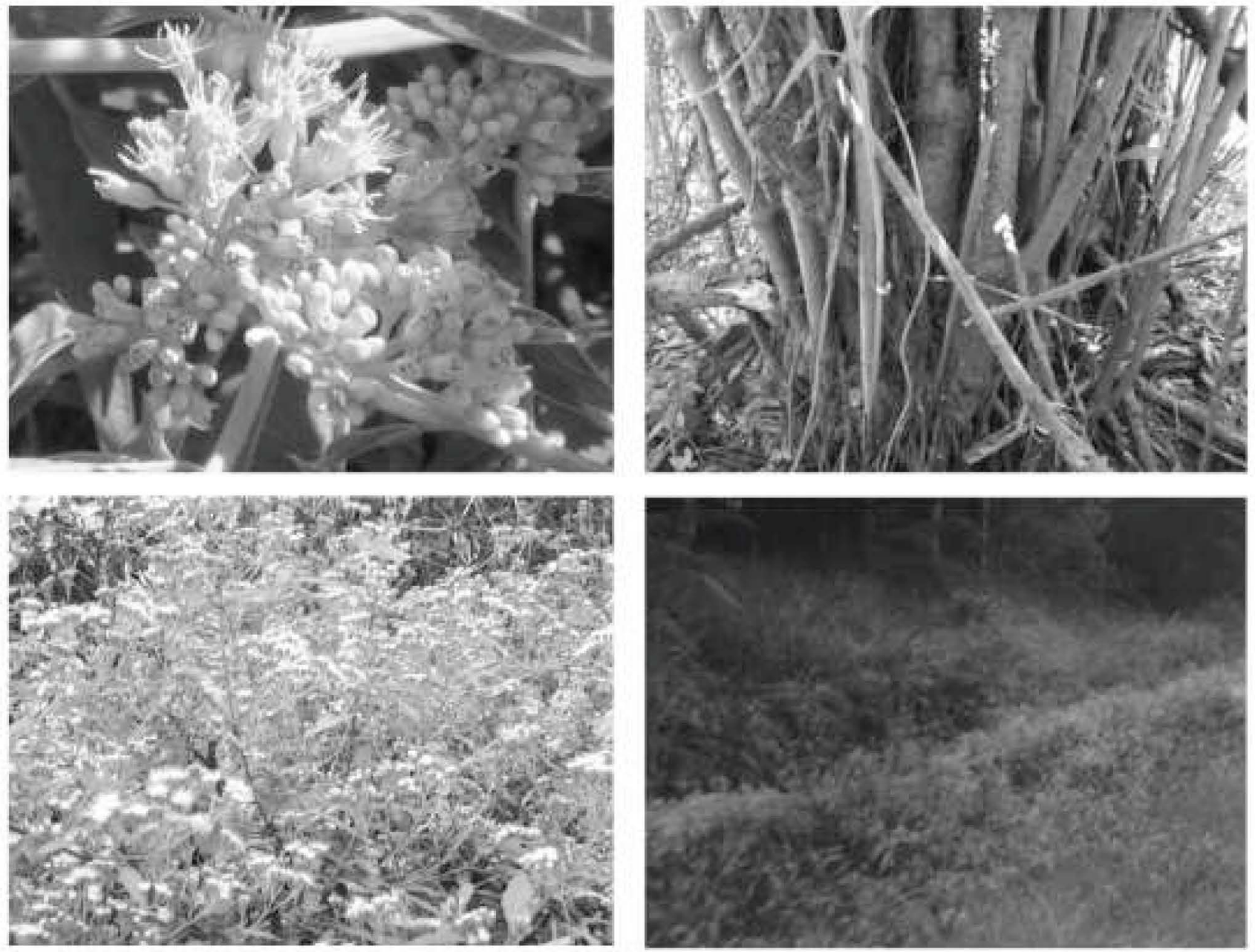

Figure 3. Above: flowers (left) and dense thicket (right) of $A$. inulifolium on the research sites. Below: flowers (left) and abundance of $A$. riparia interspersed with grasses (right) 

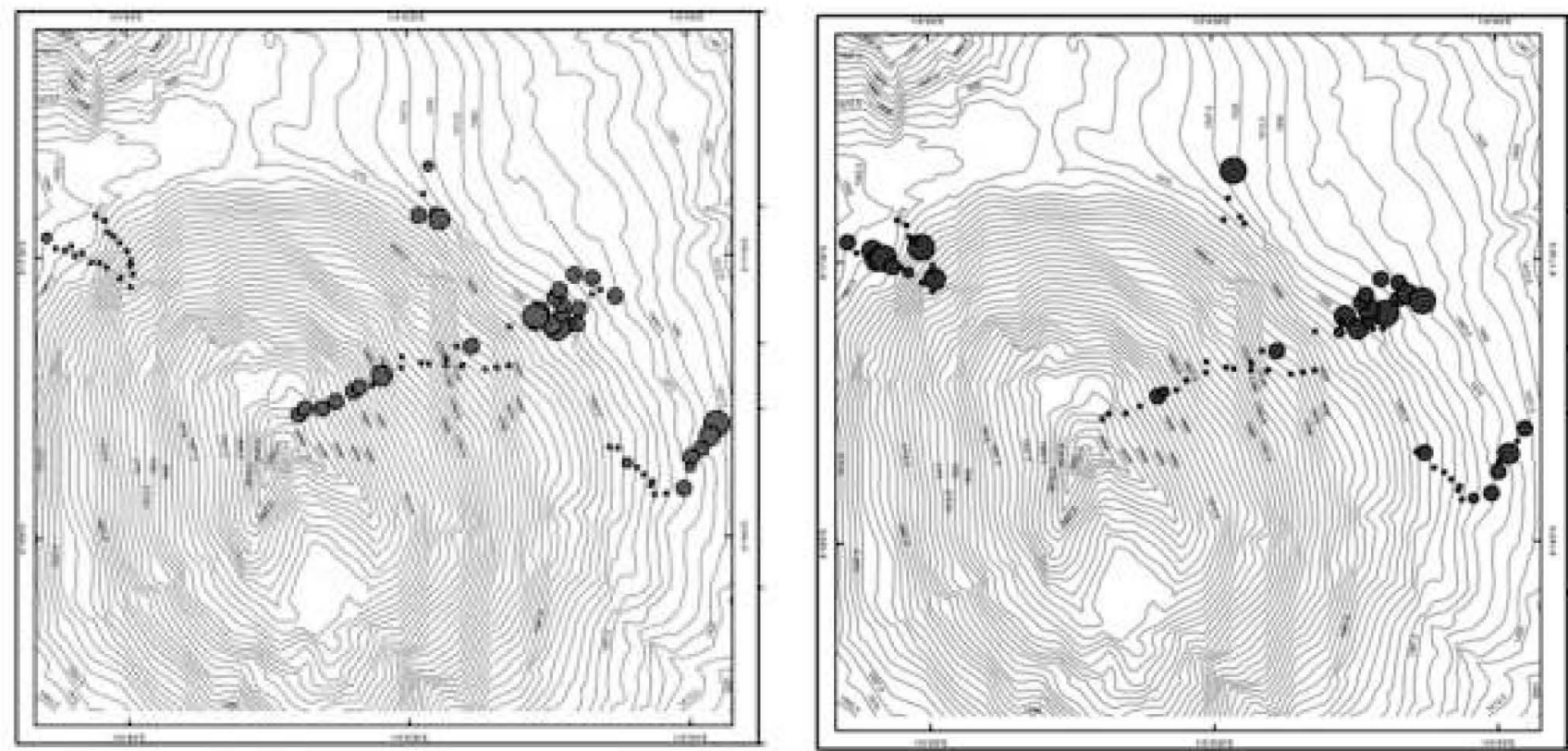

Figure 4. Distribution of $A$. inulifolium (left) and $A$. riparia (right) in Mt Pohen based on the proportion of species cover abundance overlaid on contour map.

is fast-growing perennial shrub which has potential as aggressive competitor and forms dense stands that prevent the establishment of other plant species. Similarly, Ageratina riparia is a perennial herb which grows very fast has the potential of becoming the dominant. It is prolific seeder with high reproductive potential and highly mobile propagules (Barreto and Evans 1988).

\subsection{Distribution of Invasive Asteraceae along altitudinal gradients}

A. inulifolium and A. riparia covers large area from lowest elevation sites (forest borders) up to the highest peak of the Mt Pohen. A. inulifolium was observed in wide distribution reaching the highest peak of the Mt Pohen (2035 m dpl), while A. riparia also reached the elevation up to around $1950 \mathrm{~m} \mathrm{dpl}$ (Figure 4). ) Both invaders particularly invaded the most disturbed sites correlate with the forest edge, as showed by their high frequency and abundance at the lower altitude. While site 3 in this forest habitat was highly invaded by $A$. inulifolium and A. riparia, others were sparsely invaded. However, high abundance of $A$. inulifolium at the higher elevation was also clearly noticed. These results indicate that both invasive plants are able to percolate deep into the forest interior.

Invasive plants typically need high light and nutrients that are best provided along the edge environments (Watkins et al., 2003 and Pauchard and Alaback 2006). The spreading non-forest species into forest interior highly depend on the site characteristics, and disturbed forest habitats affected by fire likely facilitate the establishment of invaders. The species traits (high propagule) and the on-going human disturbance along the forest tracks also likely explain current distribution and the possibility of expanding its range into the forest interior.

Invasion is identified as a serious threat to tropical mountains and its impacts are especially damaging in native forests that have undergone disturbance, while the upper-mountain regions are even more critically vulnerable (Burke 2003). In forest habitats that have undergone disturbance, such as humaninduced and fire affected areas, the Asteraceae invaders occurred in a high abundance. Dense stands of A. inulifolium which form impenetrable thickets clearly indicate the successful replacement of native plants by this forest invader, and this can lead to further influences ecosystem structure and species composition. Alien invasions often change the physical and biotic environment to alter the dominance or eliminate native species from an ecosystem, particularly through processes of competition and replacement. Following fire disturbance, these invasive plants have likely disrupted the forest succession by restricting native plant growth and recruitment, and this can also lead to reduced species richness of native plants, and further resulted devastating effects on the survival of specialist with limited ranges and small population sizes (Chandrasekaram and Swamy 2002; Riddock et al. 1991). Furthermore, the Asteraceae invaders identified as likely increasing along the altitudinal gradients. This underlines that the greatest environmental impacts are obviously damaging the native forests and these invaders should be given the greatest attention and the highest priority for eradication. 


\section{CONCLUSIONS}

The general patterns provided an insight of Asteraceae mountain invaders, the A. inulifolium and A. riparia, and forest disturbance (fire and human disturbance) as reliable explanation underlying their spread into higher elevation. Due to its facility to regenerate and its fast invasion, both Asteraceae invaders have the potential as greatest weed threat to Bedugul Reserve. This study provides a baseline data for conservation managers to detect, control and monitor the invasive plants within the nature reserve. Further research need to be done to determine the environmental and biotic factors that influence their presence and abundance.

\section{ACKNOWLEDGMENTS}

We are grateful for financial support from SEAMEO BIOTROP. The author would also like to thank to Dr. M. Ali Imron and the staff of the Forestry Department, Gadjah Mada University, and Abd Rahman Asy-syakur, Udayana University. Thanks also to Dr. R. Hendrian MSc., the director Purwodadi Botanic Garden. And we thank to all people who contributed to fieldwork and data collection.

\section{REFERENCES}

Barreto, R. W., \& Evans, H. C. 1988. Taxonomy of a fungus introduced into Hawaii for biological control of Ageratina riparia (Eupatorieae; Compositae), with observations on related weed pathogens. Transactions of the British Mycological Society, 91 (1): 81-97.

Burke, A. (2003). Inselbergs in a changing worldglobal trends. Diversity and Distributions, 9 (5): 375-383.

Chandrasekaran, S., \& Swamy; P. S. (2002). Biomass, litterfall and aboveground net primary productivity of herbaceous communities in varied ecosystems at Kodayar in the western ghats of
Tamil Nadu. Agriculture, ecosystems \& environment, 88 (1): 61-71.

Dawson, W., Burslem, D. F., \& Hulme, P. E. (2011). The comparative importance of species traits and introduction characteristics in tropical plant invasions. Diversity and distributions, 17 (6): 1111-1121.

Global Invasive Species Database (2016) Species profile: Austroeupatorium inulifolium. Downloaded from http://www.iucngisd.org/gisd/ species.

Global Invasive Species Database (2016) Species profile: Ageratina riparia. Downloaded from http://www.iucngisd.org/gisd/species.

Haluwana, N., \& Madawala, H. M. S. P. (2014). Changes in plant diversity and composition across forest edges bordered by Austroeupatorium inulifolium invaded grasslands in the Knuckles Conservation Area, Sri Lanka. Ceylon Journal of Science (Biological Sciences), 42 (2): 29-43.

Hobbs, R. J., \& Huenneke, L. F. (1992). Disturbance, diversity, and invasion: implications for conservation. Conservation biology, 6(3): 324337.

Pauchard, A., \& Alaback, P. B. (2006). Edge type defines alien plant species invasions along Pinus contorta burned, highway and clearcut forest edges. Forest Ecology and Management, 223(1): 327-335.

Richardson, D. M., \& Pyšek, P. (2006). Plant invasions: merging the concepts of species invasiveness and community invasibility. Progress in Physical Geography, 30 (3): 409-431.

Riddoch, I., Grace, J., Fasehun, F. E., Riddoch, B., \& Ladipo, D. O. (1991). Photosynthesis and successional status of seedlings in a tropical semi-deciduous rain forest in Nigeria. The Journal of Ecology, 491-503.

Watkins, R. Z., Chen, J., Pickens, J., \& Brosofske, K. D. (2003). Effects of forest roads on understory plants in a managed hardwood landscape. Conservation Biology, 17(2): 411-419. 